\title{
The Impact of the Financial Performance on Capital Structure of Insurance Industry in Egypt
}

\author{
Salah Mohamed Eladly ${ }^{1}$ \\ ${ }^{1}$ Lecturer, Higher Institute of Advanced Studies, Giza, Egypt \\ Correspondence: Salah Mohamed Eladly, Lecturer, Higher Institute of Advanced Studies, Giza, Egypt.
}

Received: April 13, 2021

Accepted: June 15, 2021

Online Published: June 25, 2021

doi:10.5539/ibr.v14n7p103

URL: https://doi.org/10.5539/ibr.v14n7p103

\begin{abstract}
This paper attempts to investigate the impact of the profitability and liquidity on capital structure of insurance industry in Egypt as applied on a sample of (19) insurance firms represented in the Egyptian insurance industry over the period from 1999-2019. The capital structure is measured by debt ratio, and the financial performance is measured by (liquidity, return on equity, and retune on investment).The study results show that there are significant negative linear relationships between the independent variable in terms of return on equity $\left(\mathrm{X}_{1}\right)$, return on investment $\left(\mathrm{X}_{3}\right)$, and dependent variable for the capital structure $(\mathrm{Y})$ at the level of significant less than (0.001); based on panel data analysis, the results show that Tau-statistic, and z-statistic, are at a significant level less than (0.05).The statistical conclusion is the null significant relationship between the capital structure and liquidity, while there is a significant relationship between the capital structure, return on equity, and return on investment. The results also show that the $\mathrm{R}^{2}$ for the independent variables are accepted in the model (capital structure $\mathrm{Y}$, lag $\mathrm{Y}_{1}$, return on equity $\mathrm{X}_{1}$, liquidity $\mathrm{X}_{2}$, and return on investment) by (79.3\%) from total variation of capital structure $(\mathrm{Y})$.
\end{abstract}

Keywords: capital structure, liquidity profitability (ROE and ROI), panel data analysis

\section{Regulatory and Managerial Constraint}

\subsection{Solvency Regulation}

Egyptian Financial Regulatory Authority issued Law No. (10) For the year 1981, this was amended by Law No. (91) For the year 1995, and by Law No. (27) For the year 2008. clause (14.1) of the Law states that the source capital of the insurance company should be (60) million Egyptian pounds, and the paid-up capital represents $50 \%$, and the remainder to be paid over five years period. However, if we look closely at the legislations, we will find that the government legislations dominate the financial structure of insurance companies, and that is clear in the government intervention by granting or withdrawing the licenses, for example, Clause (62) of the Egyptian law No. (10) For the year 1981 is dedicated for this purpose. As for the modern economic theory, the financial solvency analysis has been identified in two aspects: the capital and others related to pricing "Seth Chandler 95".

1-Kenny asserted that the proportion of the relationship between premiums and capital to be in the range of 2: 1, if the proportion rose to 3: 1, the Insurance Regulatory Information System of America "IRIS" will step to withdraw the license, (Gordon \& Kajiji 2004).

\subsection{Liquidity Constraints}

Capital structure has a special importance, and accordingly, clause (28) of the Egyptian Law (10) for the year 1981identifies how to allocate and invest funds:

1- The ratio of the purchased government securities, and secure certificates to paid capital at least $25 \%$

2- The ratio of shares to paid capital is $10 \%$

3- The ratio of the bonds to paid capital is $10 \%$

4- The ratio of the investment in Real Estate to paid capital is $10 \%$

5- The ratio of the grants differences to guarantee commercial mortgages to paid capital is $10 \%$

6- The ratio of the mostly cash to paid capital is 50\%

7- The ratio of the mostly other investment approved by the regulator to paid capital $10 \%$ 


\section{Literature Review}

\section{Theoretical back ground}

Modigliani\& Miller 1958 ,presented the classic theory of capital structure; at first, they claimed in their first proposition there is no relationship between the capital structure decision with the firm value and future performance under some unrealistic assumption of perfect market, the absence of bankruptcy and tax ,but lately in their second proposition M\& M 1963 , under the assumption of the imperfection market with the existence of tax subsides of interest payment, they asserted that there is a relationship between the firm value and the capital structure and future performance. Jensen and Meckling1976,demonstrated that agency cost reducing the debt financing, and the agency cost associated with the separation of ownership and control. They focused on the conflict between the managers and shareholders, as well as the conflict between the debt holders and shareholders. Ross 1977, presented a signalling effect approach which was based on asymmetric information under the assumption that the managers in trying to maximize their benefits, they will affect the financing decision process. Mayer 1984, presenting the pecking order theory, that firms prefer financing their needs from internal resources, and they adopt their dividend pay-out according to their investment opportunities. Based on this analysis the target debt ratio is not existing, but financing their capital structure upon their costs.

\section{Capital structure}

Aamer Shahzad\& et al (2020) this study attempts to determine the capital structure in the south Asian region countries; the result shows that there are significant relationships between capital structures with the liquidity, profitability, tangibility, size, economic growth, stock market development. The result shows that there is a significant relationship difference across countries and debt maturities. Merugu Venugopal \& Ravindar Reddy (2016), the results show that there is a positive direction relationship between the capital structure (debt/equity ratio), and the firm's profitability, shareholder, and market value. But statistically, there is no significant relationship between capital structure and profitability. Mercy Mandela (2016), in his article discussed the effect of capital structure on efficiency in insurance firms in Kenya. The findings indicate that the profitability and liquidity have positive effect on the firm efficiency, whereas the size of the firm and the leverage (debt ratio) are insignificant determinants of the firm efficiency. Nader Abler \&Iman Youssef (2020), the findings indicate that there are positive significant relationship between the firm size, inflation, asset tangibility, stock market development, and capital structure across country under the study, but profitability has a negatively significant relationship between and capital structure. Also, the GDP growth is not uniform across the four countries under the study, as it is positively significant except for Egypt which has a negative relationship. Jules van Binsbergen\& et al (2011), this study sought through using cost and benefit function to estimate the optimal capital structure, and the findings showed that the average at capital structure is $4 \%-13 \%$ of the firm's value.

\section{Profitability}

Michael Njogu Wahome \&et al(2015), the results show that, there are three factors (profitability, firm size and firm risk) that indicate very significant moderating impact of capital structure decisions in Kenya. The result in line with the Kenya situation whereas the financial sector in Kenya is heavily regulated just like elsewhere in the world. Mohannad Almajali and Zelhouda Shams din (2019), the findings indicate that there is a significant relationship between capital structures with the profitability of the Jordanian insurance companies, and the model analysis for the correlations is used to determine the functions relating to profitability (return on equity (ROE)) and Tobin's Q, on the capital structure (Short term debt, Long term debt and Equity). In addition to that, sales growth and the inflation rate are used as control variables. Besides, the results show that the relationship between the Standard Deviation and Long Term Debt are positively correlated with the (ROE), whereas negatively correlated with Tobin's Q, ETQ is positive correlated with all profitability; results also show that financial leverage is positively significant to profitability. Nasser Najjar and Krassimir Petrov(2011), the study result shows that there is a strong relationship between firm characteristics (tangibility of assets, profitability, and firm size, revenue growth, liquidity, and observed capital structure) as representing the capital structure measured by the Debt Ratio, although profitability and revenue growth are insignificant and require a further study. Radhi Abdul HalimRachmata, et al (2019), the finding indicates that there are significant relationship between the Capital structure on profitability and Firm value. Osuji Casmir \&Odita Anthony(2012), identified that there are negatively significant relationship between capital structure measured by (debt ratio) and the financial performance measures (return on asset, ROA, and return on equity, ROE). Tokunbo S. Osinubiet al (2019) investigated the impact of the financial leverage on the cost of debt, equity, WACC and the firm value in oil and gas companies in Nigeria; the finding indicates that the financial leverage has significant effect on cost of debt, cost of equity WACC and firm value .CindeRirihWindayu(2016) in his study investigated the relationship 
between size of the firm, sales growth, asset structure operating leverage, profitability, the characteristic/ type of industry, and the non-debt tax shield on capital structure. The findings indicate that there are many factors simultaneously affect the capital structure (size of the company, the characteristics / type of industry, sales growth, asset structure, operating leverage, Non-Debt Tax Shield and profitability). The size of the firm, industry characteristics, sales growth, asset structure and profitability are partially impacting on the capital structure, whereas the operating leverage and non-debt tax shield have no impact on the capital structure, as well as the Leverage operation has no effect on the capital structure. Muhammad Ashraf and et al (2017), the purpose of his study is to analyse the impact of capital structure measured by (long term debt, short term debt ratio interest coverage ratio and debt / equity ratio) on firm's profitability measured by (Return on Asset, Return on Equity). The findings indicate that long term debt and debt ratio have negatively significant relationship with the return on asset (ROA) and return on equity (ROE), when short term debt has a positively significant relationship with ROA and ROE. Roger J. A. Laeven \& Enrico C. Perotti(2010), the results show that the return on equity has a negative effect on total debt-equity, whereas there is a positive relationship between ROE on the debt ratio. Also the results show that the earnings before tax-sales ratio affect the return on equity negatively, whereas quick ratio has a positive effect on return on equity. Likewise, the operating profit-sales ratio has a negative relationship with liquidity. Finally, there is a negative relationship between the liquidity and profitability. Daniele Monteforte \&RaffaeleStagliano (2014) study investigates the correlation between the product diversification, international diversification on capital structure for a panel medium and large Italian firms ; the results show that there is negative significant relationship between product diversification, international diversification, and capital structure, but individually the relationship is significantly positive with capital structure. Hussin A. Abdou (2012) in his study sought to examine the key factors which determine capital structure in UK retail industry; the findings indicate that there is no significant effect between the asset growth, annual sales growth, business risk and market to book value on the capital structure. Also results show that there is a negative significant relationship between profitability, net operating profit margin, and the capital structure, but there is a positive relationship between depreciation ratio and financial leverage. Ngatemin, Azhar Maksum \& Erlina, Sirojuzilam (2018), the results show that there is a positive relationship between growth asset, ROE , debt/ asset ratio and institutional ownership, and the value of the firm. Besides, there is a negative relationship between the firm size and the firm value. T-test result shows that: the ROE and institutional ownership have significant impact on value of the firm, but there is no significant relationship between the growth asset and the value of the firm, while the firm size influence the value of the firm. Whereas the firm size has a negative relationship with the firmvalue. Yung-Ming Shiu (2011) the finding indicates that a positively significant relationship between financial leverage and reinsurance purchases, as well as reinsurance hedge, but there is a negative significant relationship between financial leverage, interact derivative, and reinsurance. Ayad S. Sultan1 \& Mustafa H. M. Adam (2015) the study results show that the capital structure positively significant on the profitability of listed firms in Iraq. Also, there is negative significant relationship between interaction profitability, and assets (firmsize) on the capital structure of the listed firms. The result is in line with the pecking order theory prediction, and the signalling effects of capital structure decisions of firms. Osaretin Kayode Omoregie\& et al (2019) this paper investigates the relationship between capital structures measured by debt ratio, on profitability is measured by return on equity, earning before tax to sales ratio and liquidity measured by quick ratio and earnings before interest and tax-to sales ratio. The findings indicate that profitability and liquidity responds similarly to capital structure. Relative to equity share of the capital structure, debt ratios has a negative effect on profitability and liquidity, while relative to asset increasing, debt has positive impact upon profitability and liquidity.

\section{Liquidity}

Mohamed Getahun (2016), this study investigated the relation between firm leverage, growth opportunity, size, risk, tangibility, and liquidity on performance in Ethiopian insurance companies. The findings indicate that there is significant relationship between firm leverage, size, tangibility and business risk with performance in Ethiopian insurance companies. However, there is insignificant relationship between growth, and liquidity and performance, while there is negative significant relationship between the leverage and performance using the regression analysis. Charles k. Ababio(2018), the study investigated the relationship between capital structure on profitability in insurance companies in Ghana using regression analysis the finding indicates that a positive significant relationship between capital structure on profitability ,also concluded that a positive relationship between firm size and the financial performance . Dimitris Margaritis \& Maria Psilaki (2007), the purpose of this study is the analysis of the relationship between the efficiency, which is measured by (size, tangible asset, intangible asset, concentration index risk profit) and financial leverage which is measured by debt to total liability. The findings indicate that there is positive significant relationship between size, concentration index which is measured by (market share), profit, and the financial leverage, but the relationship between the risks 
which is measured by (standard deviation of annual earing), and financial leverage is negative.

\section{Hypothesis \& Objective}

The topic area of the paper is the analysis of the relationship between the financial performance measured by (profitability, liquidity) and the capital structure in insurance industry in Egypt.

To examine the impact of the probability, liquidity on capital structure in insurance industry in Egypt.

In the preceding section the study, the literature review indicated that some of studies show that there is a negative significant relationship between the profitability, liquidity and capital structure, whereas other studies show that there is a positive significant relationship between profitability, liquidity and capital structure. Accordingly, the hypothesises, as the null hypothesis $\mathrm{H}_{0}$, will be:

1- There is no statistically difference between the return on equity and the capital structure

2- There is no statistically difference between the liquidity and the capital structure

3- There is no statistically difference between return on investment and the capital structure

\section{Methodology \& Research Population and Sample}

In general the capital structure is one of the most important issue for all firms since M\&M have been developed a trade- off theory of capital structure under unrealistic assumptions (1958), specially the insurance industry faced several crises in the last two decades as financial intermediate and risk aversion firms., Accordingly, the insurance companies have decided that to manage their needs form debt and equity (capital structure) to absorb their financial distress, they have to choose their capital structure accurately. So, this study sought to investigate the profitability, liquidity on capital structure, because this sector in Egypt is heavily regulated just like in other parts of the world, especially on paid capital and liquidity in their portfolio. Based on that, the study is using the panel data analysis methodology through the dynamic model along with descriptive statistics.

This part explains the population and sample of the study.The population is (39)insurance firms working in Egyptian insurance industry under the supervision of the financial regulatory authority in Egypt over the period from 1999 to 2019 , and the sample is (19) companies representing approximately $49 \%$ from the number of research population.

\subsection{Required Data}

Required data include ratio which concerning research variable, beside secondary data published by insurance companies through balance sheet and income statements. The model include(4) variable as follows:

\begin{tabular}{|l|l|}
\hline Dependent variable & $\begin{array}{l}\text { Debt Ratio } \\
\text { = Debt / Total Liabilities }\end{array}$ \\
\hline Capital Structure & \\
\hline Independent variables & Return on Equity = EBIT / Equity \\
\hline ROE & Liquidity = (Cash + Deposit + S. T. Loans + Treasure Bills) / Total Assets \\
\hline Liquidity & Return on Investment =EBIT / Total Investment \\
\hline ROI
\end{tabular}

\subsection{Statistical Tools}

To investigate the impact of the financial performance (ROE, liquidity, ROI) as independent variable and capital structure as dependent variable by using the descriptive statistics

(Mean - Median -Skewness- Kurtosis - standard deviation - (Jarque - Bera) -Probability)

\subsection{Econometrics}

Panel data analysis

\section{Research Importance\& Limitations}

This study addresses the insurance industry in Egypt specially capital structure which is determined, under supervision of financial regularity authority in Egypt, as absolute amount $60 \mathrm{M}$ Egyptian pound, and its impact on liquidity and profitability.

1- The topic area of this paper was for (20) years over the period 1999 to 2019, an acquisition between Misr Life Insurance and El Sharq Company has taken place... NASG to QNB

2- Several of the insurance firms published during the study period 


\section{Analysis Output}

\section{Jarque-Bera test, this statistical technique is used to measure the normality distribution}

Table 1. Descriptive statistics for capital structure and the financial performance variables over the period 19992019

\begin{tabular}{ccccc}
\hline Constructs & $\mathrm{Y}$ & $\mathrm{X}_{3}$ & $\mathrm{X}_{2}$ & $\mathrm{X}_{1}$ \\
\hline Mean & 0.286202 & 0.041026 & 0.203807 & 0.138785 \\
Median & 0.256739 & 0.036967 & 0.093064 & 0.139345 \\
Maximum & 0.610526 & 0.134261 & 0.918528 & 0.474458 \\
Minimum & 0.025937 & -0.046607 & 0.000106 & -0.220321 \\
Std. Dev. & 0.145313 & 0.038342 & 0.221161 & 0.141172 \\
Skewness & 0.586278 & 0.355717 & 0.998195 & 0.082026 \\
Kurtosis & 2.550631 & 2.784185 & 2.961353 & 2.899317 \\
Jarque-Bera & 26.21463 & 9.188861 & 66.28503 & 0.615960 \\
Probability & $0.001^{* * *}$ & $0.010108^{*}$ & $0.001 * * *$ & 0.734930 \\
Observations & 399 & 399 & 399 & 399 \\
\hline
\end{tabular}

*** Significant at alevel less than (0.001).

Table1 shows that the normality distribution of research variables in terms of profitability sub variable measured by return on equity ( $\left.\mathrm{X}_{1}\right)$, the finding of the Jarque-Bera test at a significant level greater than (0.05). The dependent variable (capital structure $Y$ ), and independent variables (liquidity $X_{2}$, and return on investment $\mathrm{X}_{3}$ ) are not normally distributed, since the significant of Jarque-Bera statistic is less than $(0.05)$.

Whereas Pearson skewness coefficient is between (1 to (-1)), according the table above the data is not significantly skewed.

\section{Group unit root test}

This technique is used to test the stationary of time series to ensure that the mean and variance are fixed over time, beside testing the value of the covariance between two time periods based on the distance between these periods, and not the actual time at which the covariance is calculatedfor the ROE, and liquidity on capital structure through the following statistical techniques: Augmented Dickey-Fuller (ADF), Philips-Perron (PP), I m, and Pesaran and Shin W-stat (IPSW).

Table 2. Group unit root test for dependent and independent variables from 1999 to 2019

\begin{tabular}{lllll}
\hline Method & Statistic & Prob.** & Cross- & \\
& Sections & Obs \\
\hline Null: Unit root (assumes common unit root process) & \\
\hline Levin, Lin \& Chu t* & -8.17791 & $0.001^{* * *}$ & 4 & 1590
\end{tabular}

Null: Unit root (assumes individual unit root process)

\begin{tabular}{lrlll}
\hline Im, Pesaran and Shin & & & & \\
W-stat & -11.6553 & $0.001^{* * *}$ & 4 & 1590 \\
ADF - Fisher Chi-square & 147.835 & $0.001^{* * *}$ & 4 & 1590 \\
PP - Fisher Chi-square & 199.248 & $0.001^{* * *}$ & 4 & 1592 \\
\hline
\end{tabular}

The above Table shows the stationary of the time series of the capital structure $\mathrm{Y}, \mathrm{ROE} \mathrm{X}_{1}$, liquidity $\mathrm{X}_{2}$, and ROI $\mathrm{X}_{3}$, at level $1 \sim(0)$ according to the constant level, through to the following criteria; LLC, IPSW, $\mathrm{PP}, \mathrm{ADF}$, the level of significant at $(0.05)$

\section{Co-integration equation Model}

This test measures the existence of long-term equilibrium relationships among non-stationary time series variables in terms of capital structure $\mathrm{y}$, return on equity $\mathrm{X} 1$, liquidly $\mathrm{X} 2$, and return on investment $\mathrm{X}_{3}$, as shown below: 
Table 3. Co-integration Model for dependent and independent variables from 1999 to 2019

\begin{tabular}{ccccc}
\hline Dependent & tau-statistic & Prob.* & Z-statistic & Prob.* \\
\hline $\mathrm{Y}$ & -6.253947 & $0.001 * * *$ & -71.40551 & $0.001 * * *$ \\
$\mathrm{X}_{1}$ & -8.984583 & $0.001 * * *$ & -132.5467 & $0.001 * * *$ \\
$\mathrm{X}_{2}$ & -8.278713 & $0.001 * * *$ & -114.6094 & $0.001 * * *$ \\
$\mathrm{X}_{3}$ & -8.934647 & $0.001 * * *$ & -133.1395 & $0.001 * * *$ \\
\hline
\end{tabular}

From table3the results shows that there are long-term equilibrium relationships between the dependent and independent variables from 1999 to 2019, based on the Tau-statistic, and z-statistic, at a significant level less than (0.05).

\section{Pearson correlation matrix:}

Table 4.Pearson correlation matrix

\begin{tabular}{ccccc}
\hline Constructs & $\mathrm{Y}$ & $\mathrm{X}_{1}$ & $\mathrm{X}_{2}$ & $\mathrm{X}_{3}$ \\
\hline $\mathrm{Y}$ & 1 & & & \\
$\mathrm{X}_{1}$ & $-0.407457^{* * *}$ & 1 & 1 & \\
$\mathrm{X}_{2}$ & -0.013359 & $-0.146772^{* *}$ & $-0.203725^{* * *}$ & 1 \\
$\mathrm{X}_{3}$ & $-0.175077^{* * *}$ & $0.647797^{* * *}$ & & \\
\hline
\end{tabular}

*** Significant at level less than (0.001).

** Significant at level less than (0.01).

In Table 4, findings indicate that:

There are significant negative linear relationships between the $\operatorname{ROE}\left(\mathrm{X}_{1}\right)$, ROI $\left(\mathrm{X}_{3}\right)$, and, capital structure $\mathrm{Y}$, at a significant level less than (0.001).This result is in line with Olaniyi, TaiwoAzeez\& et al(2015) the findings indicate that there is a negative significant relationship between financial leverage and firm performance, but there is a positive significant relationship between capital structure and firm performance measured by( return on asset and return on equity ), also this result concur with (AydinOzkan 2001) study whichindicates that current liquidity and profitability of firms have negative effect on their leverage decision, whereas there is a positive effect on leverage decision to the non-debt ratio and growth opportunities of firms. On the contrary of this study OngTze San and Teh Boon Heng(2018) investigated the relationship between capital structure measured by long term debt to capital, debt to capital, debt to asset, debt to equity market value, and debt to common equity, and corporate performance measured by return on capital, return on equity, earring to per share, operating margin and net income. The findings indicate that a positive relationship between return on capital, and debt to equity market value. Also there is a positive relationship between earrings per share, and Long-term Debt to Common Equity, while there is no relationship between return on asset, and earning per share; besides, there is no relationship between return on capital, return on equity, and the debt to capital.

1. There is no significant linear relationships between the independent variable of liquidity $\left(\mathrm{X}_{2}\right)$, and dependent variable, capital structure (Y), at a significant level greater than (0.05).

\section{Pedroni Residual Co-integration Test:}

Under the null hypothesis of no co-integration for panel data, the study used Pedroni residual co-integration test to specify cross section specific intercepts and homogeneous coefficient

Table 5.Pedroni Residual Co-integration Test for panel data

\begin{tabular}{|c|c|c|c|c|}
\hline \multirow[b]{3}{*}{ Panel v-Statistic } & \multirow{3}{*}{$\frac{\text { Statistic }}{-0.155404}$} & \multicolumn{3}{|c|}{ Weighted } \\
\hline & & Prob. & Statistic & Prob. \\
\hline & & $\overline{0.5617}$ & $-\overline{0.423460}$ & $\overline{0.6640}$ \\
\hline Panel rho-Statistic & 1.327720 & 0.9079 & 0.684748 & 0.7532 \\
\hline Panel PP-Statistic & -2.136751 & 0.0163 & -3.791983 & 0.0001 \\
\hline Panel ADF-Statistic & -1.047570 & 0.1474 & -2.071747 & 0.0191 \\
\hline
\end{tabular}


According to above Table, there are long-term equilibrium relationships between thecapital structure and return on equity, liquidity and return on investment of the panel data model $\left(\mathrm{Y}, \mathrm{X}_{1}, \mathrm{X}_{2}\right.$, and $\left.\mathrm{X}_{3}\right)$, based on WeightedStatistic for both Panel PP-Statistic, and Panel ADF-Statistic,at a significant level less than (0.05).

\section{Hausman Test for Correlated Random Effects:}

Table 6.Hausman Test for Correlated Random Effects

\begin{tabular}{|c|c|c|c|}
\hline \multicolumn{4}{|c|}{$\begin{array}{l}\text { Correlated Random Effects - Hausman Test } \\
\text { Equation: Untitled } \\
\text { Test cross-section random effects }\end{array}$} \\
\hline Test Summary & $\begin{array}{l}\text { Chi-Sq. } \\
\text { Statistic }\end{array}$ & Chi-Sq. d.f. & Prob. \\
\hline Cross-section random & 4.290409 & 3 & 0.2318 \\
\hline
\end{tabular}

Cross-section random effects test comparisons:

\begin{tabular}{crrrr} 
Variable & Fixed & Random & Var (Diff.) & Prob. \\
\hline $\mathrm{X}_{1}$ & -0.387231 & -0.401967 & 0.000067 & 0.0710 \\
$\mathrm{X}_{2}$ & -0.022198 & -0.024482 & 0.000008 & 0.4154 \\
$\mathrm{X}_{3}$ & 0.368854 & 0.385213 & 0.000929 & 0.5914 \\
\hline
\end{tabular}

Table 6, shows that the calculated value of the Hausman Test statistic, is not significant at a level greater than (0.05), thus, accepting the null hypothesis supporting the appropriateness of the random effects model , and rejecting the alternative hypothesis of the fixed effects model, as detailed in the first section of Table (6).

\section{Total panel estimation fixed effect model:}

Table 7. Total panel estimation fixed-effect model to determinethe effect of independent variablesonROI

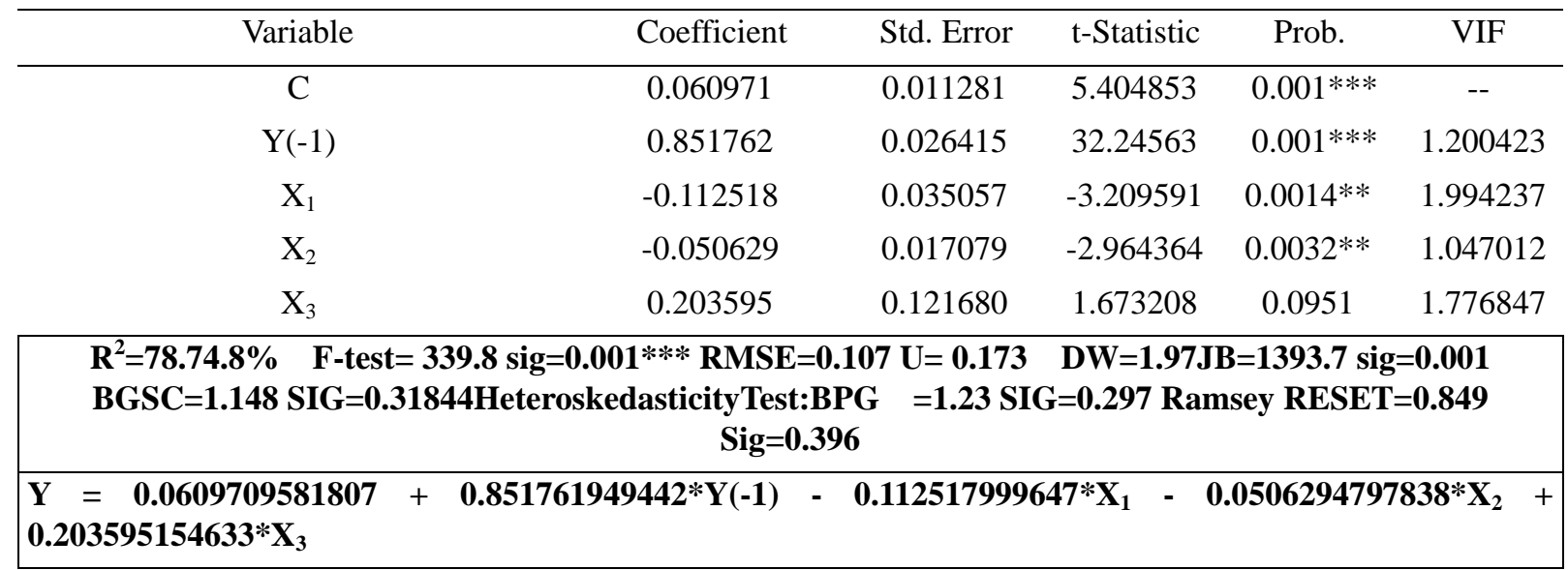

Based on outcome in table 7 the panel estimation model using least squares: ,

1. The coefficient of determination: $\mathrm{R}^{2}$

The outcome of table 7 shows that the $\mathrm{R}^{2}$ for the (ROE, liquidity and ROI) as independent variables were accepted in the model $\left(\mathrm{Y}, \operatorname{lag} \mathrm{Y}_{1}, \mathrm{X}_{1}, \mathrm{X}_{2}\right.$, and $\left.\mathrm{X}_{3}\right)$ by $(79.3 \%)$ which means that the independent variables explained $73 \%$ from variation of dependent variable (capital structure) $(\mathrm{Y})$, and $27 \%$ other independent variables are not excluded in model or either the random error in the regression model. This result is consistent with the agency cost theory for Jensen and Meckling (1976)which represent the agency cost as real as any other cost and in line with Jane Wanjiku Muiruri1 and, NemwelBosire(2015), their results show that there are positivelyrelationship between the firm size, tangibility, liquidity and printability on capital structure decision in insurance companies in Nakuru Town profitability when $R=0.69$

2. F test:

The findings of the above table indicate that the value of "F test" (339.8) at a less than (0.001) significant level, so the finding indicates that the independent variables (ROE, liquidity and ROI) were accepted in the 
model are effect on the level of capital structure (Y).

3. T-test:

The independent variables were accepted in the model are: lag $\mathrm{Y}, \mathrm{X}_{1}, \mathrm{X}_{2}$ at a significant level less than $(0.01)$.

4. VIF:

Table (7) shows the variance inflation factors; this testing is to measure multicollinearity for the financial performance variables measured by (return on equity $\left(\mathrm{X}_{1}\right)$, liquidity $\left(\mathrm{X}_{2}\right)$ and return on investment $\left(\mathrm{X}_{3}\right)$,) the value of VIF as shown on the above table (1.99- 1.047- 1.77), despite the larger the variance inflation factors, interpretation the multicollinearity, if any variance inflation factors exceed (10), then multicollinearity is a problem. The considerable range for the variance inflation factors should not exceed (4) or (5) according to the table, the value of VIP less than (4); therefore the model has not suffered from the multicollinearity problem.

\section{The Jarque-Bera Test}

In Table 7, outcome presented the Pearson skewnessvalue (.28) whereas the significance value of the test statistic $(\leq 0.05)$, then reject the null hypothesis $\left(\mathrm{H}_{0}\right)$ is rejected: residuals are normally distributed, the result indicates that the data is not significantly skewed.

\section{Theil's inequality coefficient $U$ :}

This statistically technique is used to measure the accuracy of the estimates of the random effects model. The range of this coefficient is ( 0 to 1$)$, which means that zero value indicates a perfect fit. While the value reaches up to zero (0.17) it indicates that the fitness of the model, at the level percentage equal or more than $\quad(83 \%)$.

\section{The Durbin-Watson test statistic:}

In table 7, the Durbin-Watson test statistic value is (1.97), according to durbin-watson ranges value from (0 to 4) a value near (2) indicates non-autocorrelation; a value toward (0) indicates positive autocorrelation; a value towards (4) indicates negative autocorrelation. Based on the Durbin-Watson test statistic tests the null hypothesis that the residuals from model (OLS) is not auto correlated on other hand the residuals follow( AR1) model the first - order autocorrelation is positive

\section{Breusch-Godfrey}

The outcome in table 7 provides data for Breusch - Godfrey based on the serial correlation LM test (1.148) whereas the range of the significance value of the BGSC test $(\geq 0.05) ;(0.3184)$; , based on that, the null hypothesis (H0)would not be rejected : there is no serial correlation up to lag order $\mathrm{P}$, where $\mathrm{p}$ is pre specified integer .

\section{Heteroskedasticity Test}

Table (7) shows ordinary least square as the statistical techniques; the most important assumption is that the error term has a constant variance. The table includes the Heteroskedasticity Test: Breusch-Pagan-Godfrey. The results show that, the significance level of the tests: F-statistic, Obs * R-squared, is greater than (0.05), based on outcome for the Homoscedasticity of error term which means the acceptance of the null hypothesis.

\section{Ramsey RESET Test}

Statistically, (RESET) test is a testing for the linear regression model. This test provides whether non-linear mix of the fitted values interpret the response variable. Whereas the significance level of the t-statistic, Fstatistic,Likelihood ratio test statistic $(\geq 0.05) ;(0.3961)$, according to the outcome from table7result shows that the acceptance of the null hypothesis $\left(\mathrm{H}_{0}\right)$ : This means that there are no omitted variables and the functional form is correct,

\section{Residual Cross-Section Dependence Test:}

Table 8.Residual of Cross-Section Dependence Test

\begin{tabular}{lrcc}
\hline \multicolumn{1}{r}{ Test } & Statistic & d.f. & Prob. \\
\hline Breusch-Pagan LM & 165.2923 & 171 & 0.6087 \\
Pesaran scaled LM & -1.336041 & & 0.1815 \\
Pesaran CD & 2.068308 & & 0.0386
\end{tabular}

According to table $8, \overline{\text { the significance of Breusch-Pagan LM, and Pesaran scaled LM }}$ tests, are greater than 
(0.05), the result strongly accepts the null of no correlation at conventional significance levels. This result is in line with AnupChowdhury, Suman P. Chowdhury(2010) the aim of this study is to test the effect of the financial leverage on the firm's value. The findings indicate that cost of capital has a negative correlation in capital structure decision. Also notice that by changing the debt /equity composition a firm can increase its value in the market.

The last line presents the result of the Pesaran CD test which is asymptotically standard normal, and the test statistic results due to a strongly reject to the null at conventional levels i.e. there is cross-section dependence (correlation) in residuals

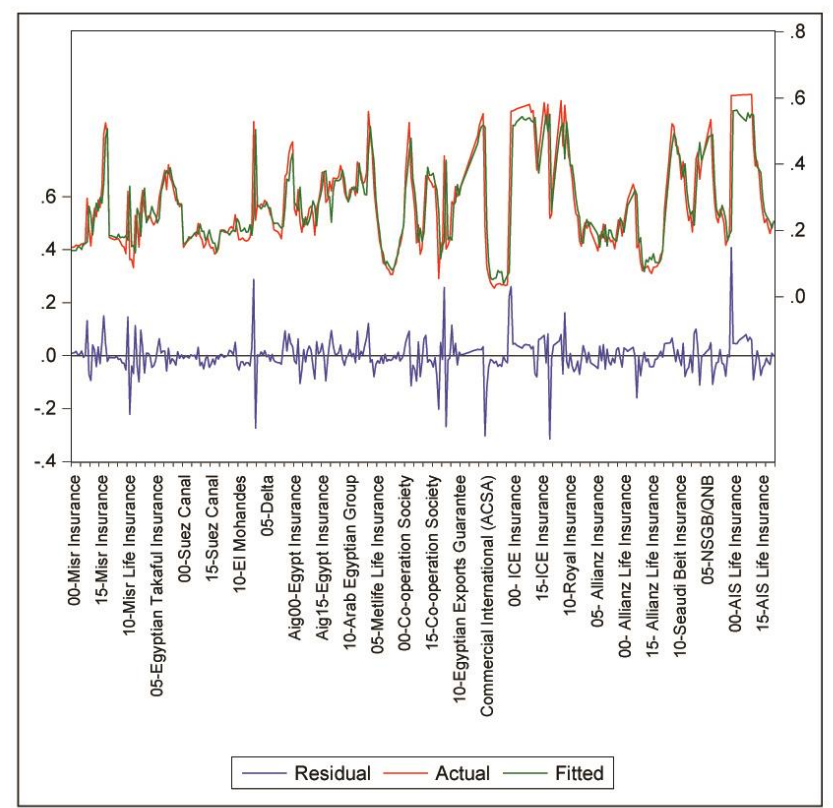

Figure 1. Residual-Actual-Fitted for the dependent and in
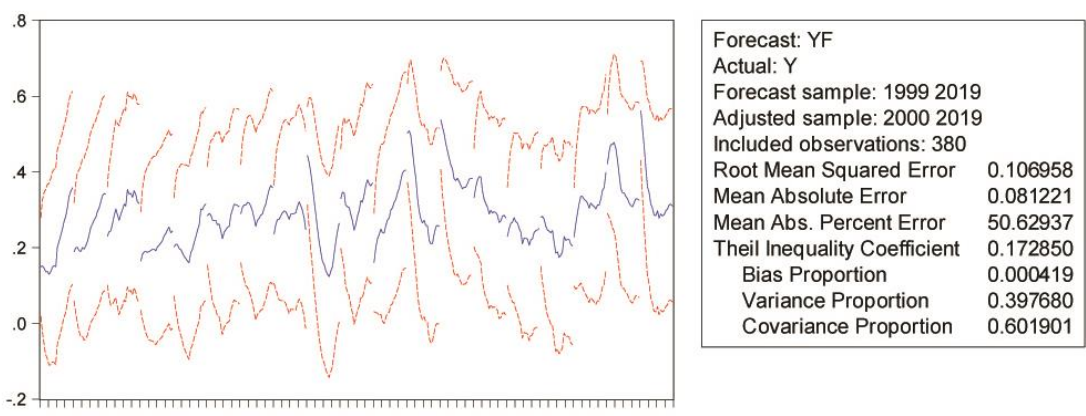

Forecast sample: 19992019 Adjusted sample: 20002019 Included observations: 380

Root Mean Squared Error $\quad 0.106958$

Mean Absolute Error $\quad 0.081221$

Mean Abs. Percent Error $\quad 50.62937$

Theil Inequality Coefficient 0.172850

Bias Proportion $\quad 0.000419$

Variance Proportion $\quad 0.397680$

Covariance Proportion $\quad 0.601901$

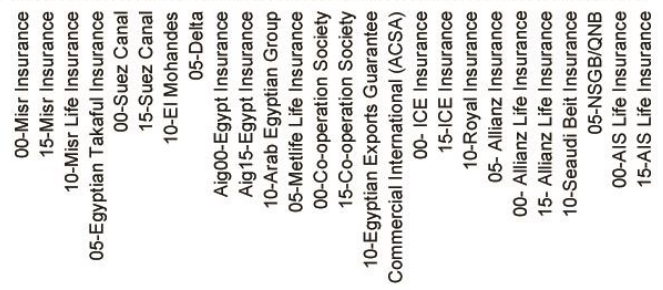

Figure 2. Variance, Covariance, Bias Proportion / Theil Inequality Coefficient 


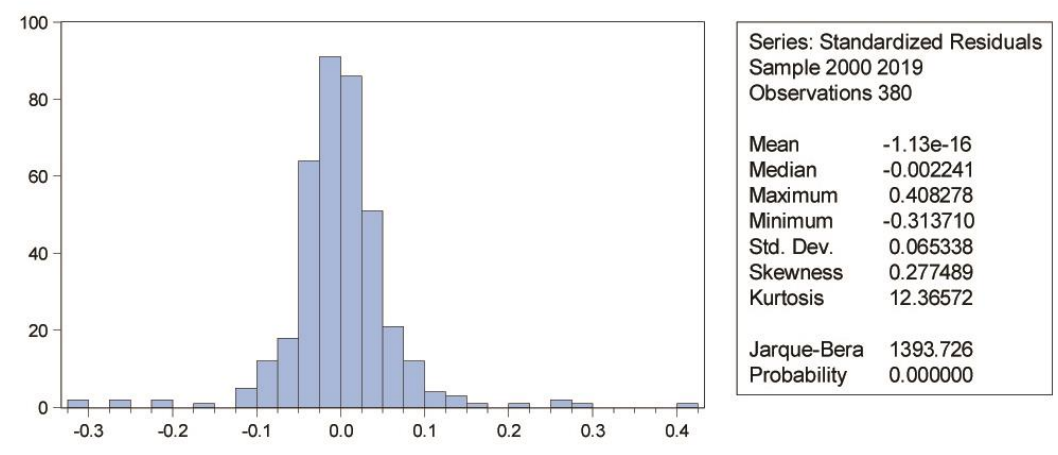

Figure 3. Standardized Residuals Sample

\section{Conclusion}

This study attempts to analyse the impact of the relationship between the profitability and liquidity on capital structure of the insurance firms in Egypt as applied on a sample of (49\%) from insurance firms working under superficially of Egyptian financial authority over the period (1999 - 2019)

According to Pearson correlation matrix the results show that:

There are significant relationship between the Capital Structure and Return on Equity Return on Investment, this result is in line with Charles k. Ababio(2018), and in line with pecking order theory by Stewart Mayer 1984 that due to asymmetric information, firms prefer internal sources rather than external sources. On other hand the There is no a significant relationship between the capital structure and liquidly. This result is in line with Albert Danso\& et, al (2020) whose study investigated the variables which have an effect on capital structure in Japanese firms, the study results show that there is a negative significant relationship between the profitability, liquidity, and growth rate on capital structure;on the other hand there are positive significant relationship between the volatility, and size on capital structure. Moreover, according to Muhammad RaghibZafa\& et al (2016), the results show that there are negative relationships ratio of (total debt / total equity) .(ROA), (ROE) and earning per share (EPS), moreover, he also concluded that there is a positive relationship between capital structure and profitability of banks in Pakistan

Based on the panel data analysis, the findings indicate that the $\mathrm{R}^{2}$ for the independent variables were accepted in the model $\left(\mathrm{Y}, \operatorname{lag} \mathrm{Y}_{1}, \mathrm{X}_{1}, \mathrm{X}_{2}\right.$, and $\mathrm{X}_{3}$ ) by $(79.3 \%$ ) which means the (ROE liquidity and ROI ) as independent variables explained $79 \%$ of variation independent variable capital structure $(\mathrm{Y})$; the findings indicate that there are long-term equilibrium relationships between the capital structure (Y)and the financial performer measured by profitability and liquidity however the profitability measured by (ROE , ROI ) as the independent variablesover the period( 1999 - 2019), depend on the Tau-statistic, and z-statistic, tests at a significant level less than (0.05).

\section{References}

Aamer, S. et al (2020). the determinants of capital structure: Evidence from SAARC countries. international Journal of Finance \& Economic, 25(4).

Albert, D. et al (2020). Capital structure revisited. Do crisis and competition matter in a Keiretsu corporate structure? International Journal of finance and economic, 25(3).

Allan, G, B. (2019). Elementary Statistics A Brief Version McGraw hill (8th ed.).

Anup, C., \& Suman, C. (2010). Impact of capital structure on firm's value: Evidence from Bangladesh. journal of business and economic horizon, 3(3).https://doi.org/10.15208/beh.2010.32

Ayad, S. S., \& Mustafa, H. M. A. (2015). The Effect of capital structure on profitability: an empirical analysis of listed firms in Iraq. European Journal of accounting, Auditing and Finance Research, 3(2).

Aydin, O. (2001). Determinants of Capital Structure and Adjustment to Long Run Target: Evidence from UK Company Panel Data. Journal of Business Finance \& Accounting, 28(1). https://doi.org/10.1111/1468-5957.00370 
Cinde, R. W. (2019). Factors Affecting the Capital Structure in Textile and Garment Listed in Indonesia Stock Exchange. journal of business and management, 18(10).

Daniele, M., \& Raffaele, S. (2014). Firm Complexity and Capital Structure: Evidence from Italian Diversified Firms. journal of managerial and decision economic, 36. https://doi.org/10.1002/mde.2660

Dimitris, M., \& Maria, P. (2007). capital structure and the firm efficiency. journal of business finance \& accounting, 34(9).

Glenn, M. (1989).an analysis of the capital structure of an insurance companies.

Gordon, H., \& Kajiji, N. (2004). Non Linear Hierarchical Modelling for Efficient Asset-Liability Management of Property-Liability Management. European Conference on operational Research, Rhodes-Greece.

Hussin, A. A. et al (2012). determinants of capital structure in the UK retail industry: a comparison multiple regression and generalized regression neural network. intelligent system in accounting, financial and management, 19. https://doi.org/10.1002/isaf.1330

Jane, W. M., \& Nemwel, B. (2014). Determinants of Capital Structure Decisions of Listed Insurance Companies in Kenya: A Survey of Insurance Companies in Nakuru Town. International Journal of Scientific Engineering and Research, 3(3).

Jensen, M., \& Meckling, W. (1976). Theory of the Firm: Managerial Behaviour, Agency Costs and Ownership Structure. Journal of Financial Economics, 3. https://doi.org/10.1016/0304-405X(76)90026-X

Jules, van B. et al (2011). an empirical model of optimal capital structure. Journal of Applied Corporate Finance, 23(4). https://doi.org/10.1111/j.1745-6622.2011.00351.x

Mercy, M. (2016). Effect of Capital Structure on Efficiency of the Insurance Companies in Kenya. Nairobi University.

Merugu, V., \& M Ravindar, R. (2019). Impact of capital structure on firm's profitability and shareholder wealth maximization: A study of listed Indian cement companies. Journal of Business and Management, 18(4).

Michael, N. W. et al (2015).the effects of firm size and risk on Capital Structure decisions of Insurance Industry in Kenya. International Journal of Scientific and Research Publications, 5(8).

Modigliani, F., \& Miller, M. H. (1958). the cost of capital, corporate finance and the theory of the investment. American economic review, 48.

Mohammed, G. (2016). Capital Structure and Financial Performance of Insurance Industries in Ethiopia. global journal of management and business research finance, 16(7).

Muhammad, A. et al (2017). The impact of the capital structure on firm's profitability: a case study of cement industry of Pakistan. International Journal of Business and Social Science, 8.

Muhammad, R. Z. et al (2016). Impact of Capital Structure on Banking Profitability. International Journal of Scientific and Research Publications, 6(3).

Myers, S. (1984). The capital structure puzzle. Journal of Finance, xxxix(3). https://doi.org/10.1111/j.1540-6261.1984.tb03646.x

Nader, A., \&Iman, Y. (2020). Capital Structure Determinants: A Cross-Country Analysis International business research, 13(5). https://doi.org/10.5539/ibr.v13n5p95

Nasser, J. N., \&Krassimir, P. (2011). capital structure of insurance company in Bahrain. International of business and management, 6(11). https://doi.org/10.5539/ijbm.v6n11p138

Osaretin, K. O. et al (2019). Capital Structure and the Profitability-Liquidity Trade-off. International Journal of Economics and Financial, 9(3). https://doi.org/10.32479/ijefi.7758

Osuji \& Odita, A. (2012). (Impact of capital structure on the financial performance of Nigerian Firms).Arabian Journal of Business and Management Review, 1(12). https://doi.org/10.12816/0002231

Paul, N.,\& Bill, Y.(1999). A Financial Approach for Determining Capital Adequacy and Allocating Capital for Insurance Companies.

Roger, J. A. L., \& Enrico, C. P. (2010). Optimal Capital Structure for Insurance Companies, Netspar. Retrieved from https://dx.doi.org/10.2139/ssrn.1730231

Stephen, A. R. (1977). the determination of financial structure: the incentive-signalling approach. The Bell Journal of economics, 24. 
Titman, S. (1984). The Effect of Capital Structure on a Firm's Liquidation Decision. Journal of Financial Economics, 13. https://doi.org/10.1016/0304-405X(84)90035-7

Yung, M. S. (2011). reinsurance and capital structure evidence from the UK non-life insurance industry. the journal of risk and insurance, 78(2). https://doi.org/10.1111/j.1539-6975.2010.01387.x

\section{Copyrights}

Copyright for this article is retained by the author(s), with first publication rights granted to the journal.

This is an open-access article distributed under the terms and conditions of the Creative Commons Attribution license (http://creativecommons.org/licenses/by/4.0/). 